\title{
Ticks infesting captive and free-roaming wild animal species at the São Paulo Zoo, São Paulo, Brazil
}

\author{
Carrapatos infestando espécies de animais silvestres cativas e de vida livre no Zoológico de São Paulo, \\ São Paulo, Brasil \\ Irys Hany Lima Gonzalez'; Marcelo Bahia Labruna ${ }^{2}$; Carolina Romeiro Fernandes Chagas ${ }^{1}$; \\ Paula Andrea Borges Salgado ${ }^{1}$; Cauê Monticelli ${ }^{1}$; Luan Henrique Morais ${ }^{1}$; Amanda Alves de Moraes'; \\ Thatiane Cristina Antunes ${ }^{1}$; Patrícia Locosque Ramos ${ }^{1}$; Thiago Fernandes Martins ${ }^{2 *}$ \\ ${ }^{1}$ Fundação Parque Zoológico de São Paulo - FPZSP, São Paulo, SP, Brasil \\ ${ }^{2}$ Departamento de Medicina Veterinária Preventiva e Saúde Animal, Faculdade de Medicina Veterinária e Zootecnia - FMVZ, \\ Universidade de São Paulo - USP, São Paulo, SP, Brasil
}

Received May 3, 2017

Accepted May 30, 2017

\begin{abstract}
Ticks are ectoparasites of worldwide distribution that affect vertebrates and can transmit pathogens to animals and humans. The Zoological Park Foundation of São Paulo (FPZSP) is located in a Conservation Unit in one of the most important remaining fragments of the Atlantic Rainforest biome in the suburbs of São Paulo, Brazil. The FPZSP houses more than 3,000 wild animals on exhibit, in breeding programs and in environmental education programs, and also attracts migratory birds and free-roaming wildlife. This study focused on identifying the diversity of tick species that infest captive and free-roaming animals at the FPZSP. The collection of ticks kept at the FPZSP contains 523 specimens that were collected from different host species between 1990 and 2017. Ten tick species were found. In addition, Amblyomma aureolatum (Pallas) was found on stray cats living in the Atlantic forest fragment in the FPZSP. This study reveals a low occurrence of parasitism in captive animals and a high diversity of tick species collected from hosts in this Atlantic forest fragment, contributing information about host-parasite relationships and potential vectors of zoonotic diseases, since the vectors of Brazilian spotted fever, A. aureolatum and Amblyomma sculptum Berlese, were found in some hosts.
\end{abstract}

Keywords: Ticks, wild animals, zoo, Atlantic forest.

\section{Resumo}

Os carrapatos são ectoparasitas da classe Arachnida, conhecidos como importantes vetores de agentes infecciosos para animais e humanos. A Fundação Parque Zoológico de São Paulo (FPZSP) localizada em uma Unidade de Conservação do bioma Mata Atlântica e inserida na cidade de São Paulo, mantém mais de 3.000 animais selvagens cativos, abrigando ainda diversas espécies silvestres nativas da Mata Atlântica. Devido à importância do conhecimento dos carrapatos que parasitam a fauna selvagem, o objetivo deste trabalho foi identificar a coleção de carrapatos da FPZSP e analisar a diversidade desses parasitas em animais cativos e de vida livre. O acervo de carrapatos mantidos pela FPZSP contém 523 exemplares que foram coletados de diferentes espécies hospedeiras, desde 1990 até 2017. Dez espécies de carrapatos foram encontradas. Além dos animais silvestres, foram encontrados Amblyomma aureolatum (Pallas) em gatos domésticos errantes que circulam nas áreas da FPZSP. Este trabalho demonstra a baixa ocorrência de parasitismo em animais cativos e a alta diversidade de carrapatos nos hospedeiros deste fragmento de Mata Atlântica, contribuindo com informaçóes sobre a relação parasita-hospedeiro e potenciais vetores de doenças zoonóticas, já que os vetores da Febre Maculosa Brasileira A. aureolatum e Amblyomma sculptum Berlese, foram encontrados em alguns hospedeiros.

Palavras-chave: Carrapatos, animais silvestres, zoológico, Mata Atlântica. 
Ticks are ectoparasites of worldwide distribution that affect vertebrates and can transmit pathogens to animals and humans (GUGLIELMONE et al., 2014; NAVA et al., 2017). The host specificity of ticks is variable; some species are associated with specific groups of hosts while other species are less selective. Generally, larvae and nymphs of species that must infest more than one host species to complete their life cycles feed on small animals, while adult ticks prefer to parasitize medium and large sized-animals (BARROS-BATTESTI et al., 2006; ESSER et al., 2016).

The Zoological Park Foundation of São Paulo (FPZSP) is located in a Conservation Unit covering an area of 824,529 square meters in the Fontes do Ipiranga State Park (PEFI), one of the most important remaining fragments of the Atlantic forest biome in the suburbs of São Paulo, southeastern Brazil. The FPZSP, which maintains more than 3,000 wild mammal, bird, reptile, amphibian and invertebrate species, in breeding programs, also provides sanctuary for migrating birds and free-roaming animals (ZOOLÓGICO DE SÁO PAULO, 2017)

The role played by modern zoos is not only to preserve the quality of life of captive animals but also to find ways to preserve wild animals and their habitats. Thus, when a free-roaming wild animal is debilitated it is cared for by a specialized support team from the FPZSP, which includes a close examination to detect the presence of ectoparasites. As a result, this institution started a collection of ticks removed from captive and free-living wildlife, which now contains hundreds of specimens.

The purpose of this study was to identify the tick species that have been collected from captive animals in the FPZSP, and from free-roaming animals living in the PEFI.

From 1990 to 2017, ticks were collected from animals kept by the Department of Applied Research, including captive and free-living wild animals at the FPZSP and PEFI. During the handling or clinical examination of animals, ticks were manually removed from their hosts and immediately stored in plastic vials containing $70 \%$ ethanol for subsequent taxonomic identification under a stereomicroscope, based on taxonomic keys and corresponding literature (ARAGÃO \& FONSECA, 1961; ONOFRIO et al., 2006a, b, 2009; MARTINS, T., et al., 2010, 2016). The nomenclature used for the identification of bird and mammals followed Sick (1997) and Reis et al. (2011), respectively.

A total of 523 tick specimens were collected (163 males, 309 females, 44 nymphs and 7 larvae) from 156 hosts belonging to 13 different wildlife species, four of them captive, nine free-living, and one of unknown origin. The sampled animals comprised: one green-winged saltator (Saltator similis d'Orbigny \& Lafresnaye), one opossum (Didelphis sp.), 101 Brazilian common opossums (Didelphis aurita Wied-Neuwied), one short-tailed opossum (Monodelphis americana Müller), ten porcupines [one Coendou sp., nine Sphiggurus villosus (Cuvier)], three red howler monkeys (Alouatta guariba clamitans Cabrera), two small wild rodents (Akodon sp. and Oligoryzomys sp.), one capybara [Hydrochoerus hydrochaeris (Linnaeus)], 32 brown-throated sloths (Bradypus variegatus Schinz), one southern tamandua [Tamandua tetradactyla (Linnaeus)], one crab-eating fox [Cerdocyon thous (Linnaeus)], and two lowland tapirs [Tapirus terrestris (Linnaeus)].

The following tick species were found: Amblyomma aureolatum (Pallas) on A. guariba clamitans and C. thous; Amblyomma calcaratum
Neumann on T. tetradactyla; Amblyomma dubitatum Neumann on $H$. hydrochaeris; Amblyomma fuscum Neumann on Didelphis sp.; Amblyomma longirostre (Koch) on S. similis, Coendou sp. and S. villosus; Amblyomma parkeri Fonseca \& Aragão on A. guariba clamitans and S. villosus; Amblyomma sculptum Berlese on T. terrestris; Amblyomma varium Koch on B. variegatus; Amblyomma sp. on A. guariba clamitans and B. variegatus; Ixodes loricatus Neumann on D. aurita, M. americana, Akodon sp., and Oligoryzomys sp.; and Rhipicephalus sanguineus (Latreille) sensu lato on T. terrestris. Detailed results are listed in Table 1.

Although most of the tick-host reports cited in this study have been reported in earlier studies conducted in Brazil and in Argentina (FONSECA, 1933; ARAGÃO, 1936; LABRUNA et al., 2005, 2007, 2009; MARTINS, J., et al., 2006; MARTINS, T., et al., 2009, 2013, 2015; GUGLIELMONE \& NAVA, 2011), the present study demonstrates new heretofore unpublished associations between stages of ticks and hosts, namely adults of I. loricatus on M. americana and on Akodon sp., A. varium nymph on $B$. variegatus, and $R$. sanguineus s.l. on T. terrestris.

In previous studies, immature stages of $I$. loricatus were found on M. americana, Monodelphis dimidiata (Wagner) and Monodelphis sorex (Hensel) (GUGLIELMONE et al., 2011), and on Akodon azarae Fischer (GUGLIELMONE \& NAVA, 2011). Our identification of adults of $I$. loricatus on $M$. americana and Akodon sp. corroborates previous records about this tick species parasitizing marsupials and rodents.

Nymphs of $A$. varium have been recorded on Bradypus tridactylus Linnaeus, and Bradypus torquatus Illiger in Brazil (MARQUES et al., 2002). The present record of nymphs of $A$. varium on $B$. variegatus in the FPZSP is consistent with an earlier study which found that nymphs of this tick species use sloths of the genus Bradypus as hosts.

We report for the first time the occurrence of $R$. sanguineus s.l. on a captive T. terrestris. In Brazil, $R$. sanguineus s.l. is described as a nidicolous tick that is associated with human dwellings usually inhabited by domestic dogs, the primary host of this tick species (LABRUNA et al., 2005). While we have no information about habitat sharing by the $R$. sanguineus infested tapir and domestic dogs, this finding confirms the potential of this exotic tick to infest native wild mammals, provided they are reared under artificial conditions.

The present report of females of $A$. sculptum on $T$. terrestris supports a recent study at another zoo located in the state of Sáo Paulo (MARTINS, T., et al., 2015). It should be noted that A. sculptum is considered the main vector of Rickettsia rickettsii, the etiological agent of Brazilian spotted fever, a potentially fatal tick-borne disease in Brazil (MARTINS, T., et al., 2016).

During our study, three stray cats [Felis catus (Linnaeus)] were also captured inside the FPZSP, and one male and three females of $A$. aureolatum were collected from these cats. The tick $A$. aureolatum is incriminated as the main vector of $R$. rickettsii in Atlantic forest fragments in the São Paulo metropolitan region, where domestic dogs (its main hosts) are considered to be carriers of infected ticks from the forest to human dwellings, thereby increasing the risk of human cases of Brazilian spotted fever (SZABÓ et al., 2013; SARAIVA et al., 2014). Our findings indicate that stray domestic cats are also potential carriers of $A$. aureolatum ticks to human 
Table 1. Ticks collected from wild animals at the Zoological Park Foundation of São Paulo and the Fontes do Ipiranga State Park in São Paulo, Brazil, from 1990 to 2017, and previous records of tick-host relationship.

\begin{tabular}{|c|c|c|c|c|}
\hline Hosts & Source & Date & Ticks & $\begin{array}{l}\text { Species recorded in the } \\
\text { literature }\end{array}$ \\
\hline \multicolumn{5}{|l|}{ PASSERIFORMES } \\
\hline Saltator similis & Free-living & 2010 & 1N Amblyomma longirostre & Labruna et al. (2007) \\
\hline \multicolumn{5}{|l|}{ DIDELPHIMORPHIA } \\
\hline Didelphis sp. & Not recorded & 1990 & $33 \mathrm{~N}$ Amblyomma fuscum & Martins, T., et al. (2009) \\
\hline Didelphis aurita (101) & Free-living & $2011 / 2015 / 2016 / 2017$ & 20M, 242F Ixodes loricatus & Aragão (1936) \\
\hline Monodelphis americana & Free-living & 2015 & $1 \mathrm{~F}^{*} I$. loricatus & \\
\hline \multicolumn{5}{|l|}{ PRIMATE } \\
\hline Alouatta guariba clamitans (3) & Free-living & $2012 / 2014 / 2015$ & $\begin{array}{c}\text { 1F Amblyomma aureolatuml } \\
\text { 1N Amblyomma parkeril } \\
\text { 5L Amblyomma sp. }\end{array}$ & $\begin{array}{l}\text { Martins, J., et al. (2006) / } \\
\text { Martins, T., et al. (2013) }\end{array}$ \\
\hline \multicolumn{5}{|l|}{ RODENTIA } \\
\hline Akodon sp. & Free-living & 2016 & $1 \mathrm{M}^{*}, 2 \mathrm{~F}^{*} I$. loricatus & \\
\hline Oligoryzomys sp. & Free-living & 2016 & $2 \mathrm{~N}$ I. loricatus & $\begin{array}{l}\text { Guglielmone \& Nava } \\
\qquad(2011)\end{array}$ \\
\hline Coendou sp. & Free-living & 1991 & $1 \mathrm{M}, 1 \mathrm{~F}$ A. longirostre & Labruna et al. (2009) \\
\hline Sphiggurus villosus (9) & Free-living & $2015 / 2011 / 2015 / 2017$ & $\begin{array}{l}\text { 25M, 5F, } 1 \mathrm{~N} A \text {. longirostrel } \\
\text { 4M, 4F, 3N A. parkeri }\end{array}$ & $\begin{array}{c}\text { Fonseca (1933) / } \\
\text { Labruna et al. (2009) / } \\
\text { Martins, T., et al. (2013) }\end{array}$ \\
\hline $\begin{array}{l}\text { Hydrochoerus hydrochaeris } \\
\text { PILOSA }\end{array}$ & Captive & 1992 & 5M Amblyomma dubitatum & Martins, T., et al. (2015) \\
\hline Bradypus variegatus (32) & Free-living & 2003-2016 & $\begin{array}{c}104 \mathrm{M}, 46 \mathrm{~F}, 3 \mathrm{~N}^{*} \text { Amblyomma varium/ } \\
\text { 2L Amblyomma sp. }\end{array}$ & $\begin{array}{c}\text { Martins, T., et al. (2015) } \\
=\end{array}$ \\
\hline $\begin{array}{l}\text { Tamandua tetradactyla } \\
\text { CARNIVORA }\end{array}$ & Captive & 2008 & $1 \mathrm{M}$ Amblyomma calcaratum & Martins, T., et al. (2015) \\
\hline $\begin{array}{l}\text { Cerdocyon thous } \\
\text { PERISSODACTYLA }\end{array}$ & Captive & 2000 & $2 \mathrm{M}, 1 \mathrm{~F}$ A. aureolatum & Labruna et al. (2005) \\
\hline Tapirus terrestris (2) & Captive & 2011 & $\begin{array}{c}\text { 5F Amblyomma sculptum/ } \\
1 \mathrm{~F}^{*} \text { Rhipicephalus sanguineus sensu lato }\end{array}$ & Martins, T., et al. (2015) \\
\hline
\end{tabular}

(number of examined animals). M: male; F: female; N: nymph; L: larvae; *New host association for the tick stage.

dwellings, a fact that should also be taken into account in the surveillance of Brazilian spotted fever in the metropolitan area of São Paulo, since human cases of the disease have been recorded in the surroundings of this forest fragment (OGRZEWALSKA et al., 2012).

This paper describes the relatively low occurrence of tick parasitism on captive wild animals at the FPZSP, and at the same time demonstrates a high diversity of tick species in free-roaming animal species living in the Atlantic forest fragment of the PEFI. These findings contribute with information about host-parasite relationships and potential vectors of tick-borne diseases transmitted to animals and humans, as indicated by two main vectors of $R$. rickettsii, the ticks $A$. aureolatum and $A$. sculptum, which were found in the study area.

\section{Acknowledgements}

The authors are grateful to Dr. Alberto A. Guglielmone (at INTA, Rafaela, Argentina) for giving them access to his extensive files of Neotropical ticks. This study was financially supported by the São Paulo Research Foundation - FAPESP. The authors thank the Zoological Park Foundation of São Paulo (FPZSP) for providing the biological material.

\section{References}

Aragão HB, Fonseca F. Notas de Ixodologia. VIII. Lista e chave para os representantes da fauna ixodológica brasileira. Mem Inst Oswaldo Cruz 1961; 59(2): 115-130. PMid:13861962. http://dx.doi.org/10.1590/ S0074-02761961000200001.

Aragão HB. Ixodidas brasileiros e de alguns paizes limitrophes. Mem Inst Oswaldo Cruz 1936; 31(4): 759-843. http://dx.doi.org/10.1590/ S0074-02761936000400004.

Barros-Battesti DM, Arzua M, Bechara GH. Carrapatos de importância médico-veterinária da regiāo neotropical: um guia ilustrado para identificação de espécies. São Paulo: Vox/ICTTD-3/Butantan; 2006.

Esser HJ, Foley JE, Bongers F, Herre EA, Miller MJ, Prins HHT, et al. Host body size and the diversity of tick assemblages on Neotropical vertebrates. Int J Parasitol Parasites Wildl 2016; 5(3): 295-304. PMid:27812506. http://dx.doi.org/10.1016/j.ijppaw.2016.10.001. 
Fonseca F. Notas de acarologia. VIII. Curiosa modalidade de parasitismo em machos de Amblyomma longirostre (Kock, 1844) e comentário sobre a morfologia deste carrapato. Bol Biológico 1933; 1(2): 57.

Guglielmone AA, Nava S, Díaz MM. Relationships of South American marsupials (Didelphimorphia, Microbiotheria and Paucituberculata) and hard ticks (Acari: Ixodidae) with distribution of four species of Ixodes. Zootaxa 2011; 3086: 1-30.

Guglielmone AA, Nava S. Rodents of the subfamily Sigmodontinae (Myomorpha: Cricetidae) as hosts for South American hard ticks (Acari: Ixodidae) with hypotheses on life history. Zootaxa 2011; 2904: 45-65.

Guglielmone AA, Robbins RG, Apanaskevich DA, Petney TN, EstradaPeña A, Horak IG. The hard ticks of the world: (Acari: Ixodida: Ixodidae). Dordrecht: Springer; 2014.

Labruna MB, Jorge RSP, Sana DA, Jácomo ATA, Kashivakura CK, Furtado MM, et al. Ticks (Acari: Ixodida) on wild carnivores in Brazil. Exp Appl Acarol 2005; 36(1-2): 149-163. PMid:16082932. http://dx.doi. org/10.1007/s10493-005-2563-1.

Labruna MB, Onofrio VC, Beati L, Arzua M, Bertola PB, Ribeiro AF, et al. Redescription of the female, description of the male, and several new records of Amblyomma parkeri (Acari: Ixodidae), a South American tick species. Exp Appl Acarol 2009; 49(3): 243-260. PMid:19241123. http:// dx.doi.org/10.1007/s10493-009-9257-z.

Labruna MB, Sanfilippo LF, Demetrio C, Menezes AC, Pinter A, Guglielmone AA, et al. Ticks collected on birds in the state of São Paulo, Brazil. Exp Appl Acarol 2007; 43(2): 147-160. PMid:17882514. http:// dx.doi.org/10.1007/s10493-007-9106-x.

Marques S, Barros-Battesti DM, Faccini JLH, Onofrio VC. Brazilian distribution of Amblyomma varium Koch, 1844 (Acari: Ixodidae), a common parasite of sloths (Mammalia: Xenarthra). Mem Inst Oswaldo Cruz 2002; 97(8): 1141-1146. PMid:12563481. http://dx.doi.org/10.1590/ S0074-02762002000800014.

Martins JR, Salomão EL, Doyle RL, Teixeira MC, Onofrio VC, BarrosBattesti DM. First record of Amblyomma aureolatum (Pallas, 1772) (Acari: Ixodidae) parasitizing Alouatta guariba (Humboldt, 1812) (Primata: Atelidae) in Southern Brazil. Rev Bras Parasitol Vet 2006; 15(4): 203205. PMid:17196126.

Martins TF, Barbieri AR, Costa FB, Terassini FA, Camargo LM, Peterka $\mathrm{CR}$, et al. Geographical distribution of Amblyomma cajennense (sensu lato) ticks (Parasitiformes: Ixodidae) in Brazil, with description of the nymph of A. cajennense (sensu stricto). Parasit Vectors 2016; 9: 186. PMid:27036324. http://dx.doi.org/10.1186/s13071-016-1460-2.

Martins TF, Dantas-Torres F, Nieri-Bastos FA, Marcili A, Siqueira DB, Aléssio FM, et al. Host records for the immature stages of the South American tick, Amblyomma fuscum (Acari: Ixodidae). Entomol News 2009; 120(4): 370-374. http://dx.doi.org/10.3157/021.120.0404.

Martins TF, Onofrio VC, Barros-Battesti DM, Labruna MB. Nymphs of the genus Amblyomma (Acari: Ixodidae) of Brazil: descriptions, redescriptions, and identification key. Ticks Tick Borne Dis 2010; 1(2): 75-99. PMid:21771514. http://dx.doi.org/10.1016/j.ttbdis.2010.03.002.

Martins TF, Scofield A, Oliveira WBL, Nunes PH, Ramirez DG, BarrosBattesti DM, et al. Morphological description of the nymphal stage of Amblyomma geayi, and new nymphal records of Amblyomma parkeri. Ticks Tick Borne Dis 2013; 4(3): 181-184. PMid:23414796. http:// dx.doi.org/10.1016/j.ttbdis.2012.11.015.

Martins TF, Teixeira RHF, Labruna MB. Ocorrência de carrapatos em animais silvestres recebidos e atendidos pelo Parque Zoológico Municipal Quinzinho de Barros, Sorocaba, São Paulo, Brasil. Braz J Vet Res Anim Sci 2015; 52(4): 319-324. http://dx.doi.org/10.11606/issn.1678-4456. v52i4p319-324.

Nava S, Venzal JM, González-Acuña D, Martins TF, Guglielmone AA. Ticks of the Southern Cone of America: diagnosis, distribution and hosts with taxonomy, ecology and sanitary importance. London: Elsevier; 2017.

Ogrzewalska M, Saraiva DG, Moraes-Filho J, Martins TF, Costa FB, Pinter A, et al. Epidemiology of Brazilian spotted fever in the Atlantic Forest, state of São Paulo, Brazil. Parasitology 2012; 139(10): 1283-1300. PMid:22716923. http://dx.doi.org/10.1017/S0031182012000546.

Onofrio VC, Barros-Battesti DM, Labruna MB, Faccini JL. Diagnoses of and illustrated key to the species of Ixodes Latreille, 1795 (Acari: Ixodidae) from Brazil. Syst Parasitol 2009; 72(2): 143-157. PMid:19115087. http:// dx.doi.org/10.1007/s11230-008-9169-z.

Onofrio VC, Labruna MB, Pinter A, Giacomin FG, Barros-Battesti DM. Comentários e chaves para as espécies de Amblyomma. In: Barros-Battesti DM, Arzua M, Bechara GH. Carrapatos de importância médico-veterinária da regiāo neotropical: um guia ilustrado para identificação de espécies. São Paulo: Vox/ICTTD-3/Butantan; 2006a. p. 53-71.

Onofrio VC, Venzal JM, Pinter A, Szabó MPJ. Família Ixodidae: características gerais, comentários e chaves para gêneros. In: Barros-Battesti DM, Arzua M, Bechara GH. Carrapatos de importância médico-veterinária da regiāo neotropical: um guia ilustrado para identificação de espécies. São Paulo: Vox/ICTTD-3; 2006b. p. 29-39.

Reis NR, Peracchi AL, Pedro WA, Lima IP. Mamiferos do Brasil. 2. ed. Londrina: Edição do autor; 2011.

Saraiva DG, Soares HS, Soares JF, Labruna MB. Feeding period required by Amblyomma aureolatum ticks for transmission of Rickettsia rickettsii to vertebrate hosts. Emerg Infect Dis 2014; 20(9): 1504-1510. PMid:25148391. http://dx.doi.org/10.3201/eid2009.140189.

Sick H. Ornitologia brasileira. Rio de Janeiro: Editora Nova Fronteira; 1997.

Szabó MPJ, Pinter A, Labruna MB. Ecology, biology and distribution of spotted-fever tick vectors in Brazil. Front Cell Infect Microbiol 2013; 3: 27. PMid:23875178. http://dx.doi.org/10.3389/fcimb.2013.00027.

Zoológico de São Paulo. [online]. 2017 [cited 2017 Jan 10]. Available at: http://www.zoologico.com.br/a-fundacao/quem-somos/ 